\title{
Important Trends and Developments Influencing the Nursing Care
}

\author{
Annelie Thor ${ }^{1}$, Patrick Siegfried ${ }^{2}$ \\ ${ }^{1}$ International Management, International School of Management, Frankfurt, Germany \\ ${ }^{2}$ International Management, Logistics \& Supply Chain Management, International School of Management, Frankfurt, Germany \\ Email: patrick.siegfried@ism.de
}

How to cite this paper: Thor, A., \& Siegfried, P. (2021). Important Trends and Developments Influencing the Nursing Care. Open Journal of Social Sciences, 9, 94-101. https://doi.org/10.4236/jss.2021.92006

Received: January 4, 2021

Accepted: February 5, 2021

Published: February 8, 2021

Copyright $\odot 2021$ by author(s) and Scientific Research Publishing Inc. This work is licensed under the Creative Commons Attribution International License (CC BY 4.0).

http://creativecommons.org/licenses/by/4.0/ (c) (i) Open Access

\begin{abstract}
Aim: The aim of this scientific paper was to examine important trends and developments influencing the nursing care in order to forecast future opportunities and challenges and how to deal with them in the best possible way. Background: The Corona-pandemic demonstrated the importance of nursing care in the entire world and had drawn attention to the issue of a well-educated and enough nursing staff. The nursing care will face opportunities and challenges due to current trends and developments, which are important to examine in order to provide the best possible nursing care. Methods: To reach the above-mentioned aim, intensive research was done by using secondary sources and surveys. Results/Findings: After a detailed analysis of the research it can be summarized that there are three important topics influencing the nursing care: The demographical development with an increasing life expectancy leading to an increasing amount of old people with a demand for care and decreasing birth rates leading to less working people. Cultural transformation and diversity imply many opportunities because the employment market can fill gaps with foreign workers and the immigrating people can compensate the decreasing birth rates. Nevertheless, it can imply many challenges and potential problems which need to be solved by the society and the immigrating people. Furthermore, the changing gender roles can lead to more men becoming a nurse, which might have a significant impact on the shortage of nursing staff. The third important topic influencing the nursing care is technological trends which can help to decrease physiological stress, by facilitating the nurses' work and by taking over some work from them. Conclusion: It can be concluded that the trends and developments influencing the nursing care are very diverse and imply many different opportunities as well as challenges.
\end{abstract}

\section{Keywords}

Nursing Care, Trends, Developments, Opportunities, Challenges 


\section{Introduction}

The Corona crisis has once again shown how important excellent medical care is (Fawaz, Anshasi, \& Samaha, 2020) not only for the health of the population, but also for the economic situation of a country, as the quality of medical care has an impact on the spread and mortality of the virus and thus an influence on how strong the economic impact of a pandemic is on a country (Tagesspiegel, 2020). It is not only the primary effects of good medical care that need to be considered, but also the secondary effects, as good medical care can minimize the rate of infection and mortality, resulting in less sick leave and deaths in the workforce, which in turn puts less strain on the economy (Tagesspiegel, 2020).

Not only have the citizens in Germany now noticed how important care workers are and pay them respect, for example by clapping together on the balcony in the evening, but politicians have also noticed, at least in times of the corona crisis, how important the work of nursing staff is. Currently, a corona bonus for nursing staff is being discussed as a reaction to this, to thank them for their tireless work in times of the pandemic (Süddeutsche Zeitung, 2020).

But will the sudden appreciation lead to a rethinking of the working conditions and pay of nurses, or is it just a short-term flare-up of respect and appreciation that will fade away just like the high numbers of sick people? This remains to be seen.

Nevertheless, it is essential not to only concentrate on the current shortage of nursing staff but to also consider important trends and developments which influence the nursing care. These factors need to be examined and evaluated in order to prepare for future developments and to facilitate and modernize the work of nursing staff in the best way possible.

These trends and developments might have an impact on the workplace of nursing staff and may also influence the employees' attitude towards their job.

\section{Demographical Development}

\subsection{Decreasing Population}

Demography is "the study of changes in the number of births, marriages, deaths, etc. in a particular area during a period of time" (Cambridge Dictionary, 2019).

The demographic development is characterised by two main trends: On the one hand, the birth rates are decreasing (Statista, 2021a) and on the other hand, the life expectancy increases (Statista, 2021b) and therefore the amount of older and care-dependent people increases as well (Statista, 2021c). In 2007, the population of Germany was 82.2 million people, which is estimated to decrease to 68.8 million inhabitants in 2050 (Statista, 2019a).

This estimated development will also influence the amount of nursing staff in the hospitals. Right now, many hospitals find it difficult to hire nursing staff because of low numbers of job applicants. Since in 2017, $40 \%$ of the nursing staff in German hospitals was 50 years or older (Statistisches Bundesamt, 2019a). If these women and men will retire, the amounts of nursing staff will decrease even 
more, it will become even harder for hospitals to hire adequate nursing staff and the whole situation in hospitals regarding the care can be expected to become even worse.

\subsection{Increasing Life Expectancy}

At the same time, the life expectancy increased very much over the last decades: Men who were born in 1960-1962 have a life expectancy of 66.9 years, while women have a life expectancy of 72.4 years (Statista, 2019b). Men being born in 2015-2017 have a life expectancy of 78.4 years, while the life expectancy of women being born in 2015-2017 increased up to 83.2 years (Statista, 2019b). This development naturally leads to higher amounts of elder people: From 2010 to 2050 the amount of people being 60 years and older is estimated to increase from 18.6 million up to 27.6 million people (Statista, 2019c), even though the population in Germany is expected to continuously decrease. Since older people tend to need more medical help and stay in hospitals more often, the amount of patients will also increase, even if the population decreases. This estimated increase in patients urges action because even nowadays there are not enough nurses on the wards, wards have to be closed and operations need to be cancelled due to the shortage and this situation will become even worse, if patient numbers will increase, while the amount of nursing staff remains the same or even increases.

\section{Immigration \& Gender Transformation}

\subsection{Internationalisation \& Immigration}

Over the last decades, globalisation and internationalisation have led to tremendous changes in the business world (Siegfried 2013). In previous times, imports and exports did not play a major role in business (Statista, 2019d; Siegfried 2015a), while nowadays they are very important (Statista, 2019d; Siegfried 2015b). The same applies for the immigration to Germany, which became much more important over the last decades: In 1991, the amount of foreign people being part of the overall German population was only $7.6 \%$, which increased up to $12.2 \%$ in 2018 (Statista, 2019e).

These developments influence the everyday work not only in globalized companies, but also in hospitals. Even though they often do not work internationally, many hospitals are run by international operators, for example by the Helios $\mathrm{GmbH}$, which is the biggest provider for ambulant and stationary care in Europe with more than 130 hospitals (Helios, 2019). Furthermore, the everyday work is influenced by the increasing number of immigrants not only on the patient-side, but also regarding the personnel-side, for example foreign nurses and doctors. This development can be considered a challenge and a solution approach all at once: On the one hand, people from different countries do have other cultural backgrounds, language barriers, might have different work attitudes, etc., so that it can be difficult to integrate them into the German profes- 
sional life. However, they might make it easier for hospitals to hire nursing staff and if they successfully integrate themselves and the hospitals offer guidance and support regarding the integration, immigrants can be part of the solution approach regarding the shortage of nursing staff in German hospitals.

\subsection{Gender Difference of Nursing Staff}

Moreover, the gender ratios of nursing staff changed. Until the 1970's, only women were accepted at nursing schools and men were not allowed to learn this job because it was expected that only women enough were caring enough to do this job (Gesellschaft für medizinische Intensivpflege, 2019). Nowadays $75.8 \%$ of the nursing staff is still female (Statistisches Bundesamt, 2019b), which shows that there has been a major change regarding the gender proportion of nursing staff over the last decades.

Nonetheless this number of male nurses is still too low to be considered a solution approach to the shortage of nursing staff. The problem for men in the care is that traditional gender roles expect women to work as nurses, so that male nurses have to justify why they are working as a nurse, while they might be offended by patients for being a male nurse, which can then influence their self-esteem (Gesellschaft für medizinische Intensivpflege, 2019). A changing gender role, not only regarding the gender of nurses, but also regarding the male identity is needed, in order to make the job of nurses more attractive to men (Gesellschaft für medizinische Intensivpflege, 2019).

\section{Technological Trends}

\subsection{Information about Technological Trends}

Not only have cultural transformation and diversity influenced the everyday work of patients and nursing staff, modernisation and technological improvements already play a big role in the daily care and this role might become even bigger in the future. Right now, hospitals are using electronic beds, bells in case the patient needs help and medical technologies to make their everyday work easier and to ensure safety of the patients. In the future, robotic technology could ease the work of nurses and might also improve the patients' experiences and safety.

Scientists are currently researching, how robots could be used in the care, for example by integrating them into furniture or even developing care robots, which might for example help the patients with daily tasks and prevent falling (Ärzteblatt, 2019).

However, the acceptance of patients might complicate this development because of a low willingness to use these. A survey which was published in 2018 reveals that $90 \%$ of the interviewed people can imagine using digital technologies when they are older, for example sensors which register if a person has already woken up (Ärzteblatt, 2018). Nonetheless only 58\% of the interviewed persons would be willing to use nurse-robots and only $39 \%$ would allow robots to help 
them with their personal hygiene (Ärzteblatt, 2018).

These survey results reveal that there is not only research needed to develop nurse robots, but there needs to be a changing attitude towards robots in society as well, in order to make them usable in the nursing care.

\subsection{Analysis of the Trends \& Developments}

The trends and developments influencing the nursing care can be considered a challenge and an opportunity at the same time: A decreasing birth rate on the one hand and an increasing life expectancy on the other hand, result in an increasing demand for nursing staff because the amount of patients is growing due to the increasing life expectancy. At the same time, the decreasing birth rates also decrease the amount of future nursing staff. Immigration and the gender transformation can help to bring foreign nurses to Germany, where they can help to reduce the shortage of nursing staff. The gender transformation can make it more interesting for men to become a nurse, because it is no longer considered a job only for women, which could then also reduce the shortage of nursing staff. Technological trends can help to reduce the physical loads for nursing staff and might take over certain tasks of nurses.

\section{Research Finding}

Several trends and developments are influencing the nursing staff currently and will influence the nursing staff in the future even more. In order to take advantage of the opportunities which lie in the different trends and developments, it is very important to manage them properly and to support and strengthen these developments: Politics and the hospital companies should actively try to reach out to foreign nursing staff and make it attractive for them to work in Germany. At the same time, they should try to make the job as a nursing staff more attractive - not only for men but for all genders: For example by implementing a higher salary, better working conditions, a more balanced work-life-balance and a better compatibility of family and job. Furthermore, the hospital companies should make use of the technological innovations which can make the working life of a nurse easier and politics should give financial support to hospitals which want to use these technological innovations.

\section{Conclusion}

The decreasing population on the one hand and on the other hand, the increasing life expectancy have led to high amounts of older people, which will increase even more in the future. This development includes several problems and challenges for the German society because increasing amounts of older people have an increasing demand for care, which has to be managed by the German health system. Nevertheless, the increasing amounts of older people imply many opportunities as well, for example by increasing the age of retirement or developing models, which include older people in the employment market, but with a re- 
duced amount of time and less stressful work, so that it matches their decreasing physiological capabilities.

Just like the demographical development, the cultural transformation also implies many challenges and can lead to problems, but also implies a lot of opportunities. The employment market can fill gaps with foreign workers and the immigrating people can compensate the decreasing birth rates. At the same time, the cultural differences can also lead to many problems, which have to be solved not only by the German society, but also by the immigrating people, who need to integrate themselves and adapt to the changed cultural circumstances.

As described earlier in this master thesis, the probability of becoming sick due to physiological reasons is much higher for nurses than for people working in other jobs because the job as a nurse is much more physiologically exhausting. Technological innovations can decrease this physiological stress, by facilitating the nurses' work and by taking over some work from them. However, the nurses and also the patients, doctors and hospital managements need to accept these technologies and integrate them into the everyday work, so that it can help the nurses and make their job less stressful.

\section{Conflicts of Interest}

The authors declare no conflicts of interest regarding the publication of this paper.

\section{References}

Ärzteblatt (2018). Digitale Anwendungen in der Pflege stoßen teilweise auf Akzeptanz [Digital Treatments in the Care Areacceptedpartly]. https://www.aerzteblatt.de/nachrichten/97770/Digitale-Anwendungen-in-der-Pflege-st ossen-teilweise-auf-Akzeptanz

Ärzteblatt (2019). Wissenschaftler erforschen Robotereinsatz in der Pflege [Scientists Research Use of Robots in the Care]. https://www.aerzteblatt.de/nachrichten/100380/Wissenschaftler-erforschen-Roboterein satz-in-der-Pflege

Cambridge Dictionary (2019). Demography. https://dictionary.cambridge.org/de/worterbuch/englisch/demography

Fawaz, M., Anshasi, H., \& Samaha, A. (2020). Nurses at the Front Line of COVID-19: Roles, Responsibilities, Risks, and Rights. The American Journal of Tropical Medicine and Hygiene, 103, 1341-1342. https://doi.org/10.4269/ajtmh.20-0650

Gesellschaft für medizinische Intensivpflege (2019). Männer in Pflegeberufen [Men in Caring Jobs]. https://www.gip-intensivpflege.de/news/detail/maenner-in-pflegeberufen

Helios (2019). Helios - das Unternehmen [Helios-The Company]. https://www.helios-gesundheit.de/unternehmen/wer-wir-sind/helios-auf-einen-blick/d ie-helios-geschichte

Siegfried, P. (2013). Studies Analysis on Strategic Corporate Planning in SMEs. Entrepreneurship Conference, Lisboa, 19-23 August 2013, 618-632.

Siegfried, P. (2015a). International Management in Practice (Volume 1, pp. 97-99).

Siegfried, P. (2015b). International Management in Practice (Volume 2, pp. 110-115). 
Statista (2019a). Deutschland-Entwicklung der Bevölkerungsstruktur nach Altersgruppen [Germany-Development of the Population-Structure According to Age Groups].

https://de.statista.com/statistik/daten/studie/248090/umfrage/entwicklung-der-bevoelk erungsstruktur-deutschlands-nach-altersgruppen

Statista (2019b). Lebenserwartung in Deutschland nach Geschlecht bis 2017 [Life Expectancy in Germany for Genders until 2017].

https://de.statista.com/statistik/daten/studie/185394/umfrage/entwicklung-der-lebense rwartung-nach-geschlecht

Statista (2019c). Demographie-Bevölkerungsentwicklung in Deutschland nach Altersgruppen bis 2050 [Demography-Population Development in Germany for Age Groups until 2050].

https://de.statista.com/statistik/daten/studie/321898/umfrage/demographie-bevoelkeru ngsentwicklung-in-deutschland-nach-altersgruppen

Statista (2019d). Handelsvolumenweltweit bis 2018 [Trade Volume Worldwide until 2018].

https://de.statista.com/statistik/daten/studie/37143/umfrage/weltweites-exportvolumen -im-handel-seit-1950

Statista (2019e). Ausländeranteil in Deutschland bis 2018 [Percentage of Foreigners in Germany until 2018].

https://de.statista.com/statistik/daten/studie/14271/umfrage/deutschland-anteil-auslae nder-an-bevoelkerung

Statista (2021a). Anzahl der Geburten in Deutschlad von 1991 bis 2019.

https://de.statista.com/statistik/daten/studie/235/umfrage/anzahl-der-geburten-seit-19 $\underline{93}$

Statista (2021b). Durchschnittliche Lebenserwartung im Alter von 60 Jahren nach Geschlecht weltweit in ausgewählten Jahren von 1990 bis 2019.

https://de.statista.com/statistik/daten/studie/227327/umfrage/lebenserwartung-im-alter -von-60-jahren-weltweit-nach-geschlecht

Statista (2021c). Fallzahlen in deutschen Krankenhäusern in den Jahren 1998 bis 2018. https://de.statista.com/statistik/daten/studie/157058/umfrage/fallzahlen-in-deutschenkrankenhaeusern-seit-1998

Statistisches Bundesamt (2019a). Gesundheitspersonal [Nursing Staff]. https://www.destatis.de/DE/Themen/Gesellschaft-Umwelt/Gesundheit/Gesundheitsper sonal/gesundheitspersonal.html

Statistisches Bundesamt (2019b). Gesundheitspersonal Deutschland: Jahre, Einrichtungen, Geschlecht [Nursing Staff in Germany: Years, Institution, Gender].

https://www-genesis.destatis.de/genesis/online/logon?sequenz=tabelleErgebnis\&selecti onname $=23621-0001 \&$ zeiten $=2000,2005,2010 \&$ zeitscheiben $=3$

Süddeutsche Zeitung (2020). Warum werden Pflegekräfte so oft respektlos behandelt? Unter \#RespectNurses erzählen Pfleger ${ }^{*}$ innen von ihren üblen Erfahrungen.

https://www.jetzt.de/job/respectnurses-warum-werden-pflegekraefte-nicht-von-patient -innen-respektiert

Tagesspiegel (2020). Pandemie-Szenario der Regierung. https://www.tagesspiegel.de/berlin/pandemie-szenario-der-regierung-die-medizinische -versorgung-bricht-bundesweit-zusammen/25637470.html 


\section{Summary Statement}

What is already known about this topic?

Nursing staff is very important for the health care and also, especially during a pandemic, essential for the country's economic situation. In Germany there is a big shortage of nursing staff which gained a lot of attention during the COVID-19 pandemic

Research Findings/ Key New Information

The trends and developments influencing the nursing care are very diverse.

Different trends and developments imply various opportunities as well as challenges.

\section{The Implications of this Paper}

The research findings of this paper can help to prepare in the best possible way for future developments.

Furthermore, the research findings can also help to forecast future developments and can help to bring these trends and developments into focus. 